INSIGHTS INTO REGIONAL DEVELOPMENT

ISSN 2669-0195 (online) http://jssidoi.org/IRD/

2020 Volume 2 Number 1 (March)

http://doi.org/10.9770/IRD.2020.2.1(2)

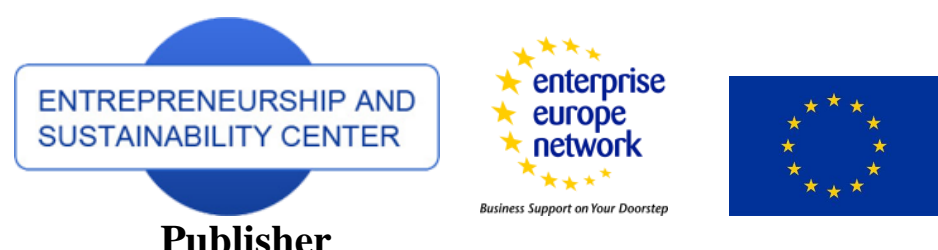

http://jssidoi.org/esc/home

\title{
ECONOMIC PHENOMENOLOGY: FUNDAMENTALS, PRINCIPLES AND DEFINITION ${ }^{1}$
}

\section{Francesco Vigliarolo}

Catholics Univetrsity of La Plata, Argentina, Street 25, between 47 and 48 streets, CP 1900, La Plata, Argentina

E-mail: fvigliarolo@gmail.com

Received 17 November 2019; accepted 18 January 2020; published 30 March 2020

\begin{abstract}
One of the tensions in economics, that has spanned the last few centuries, has undoubtedly been the dichotomy between dialectical materialism and idealism, which ended up laying the foundations between structure and superstructure, taking up the important philosophical questions faced in past centuries. This tension also ended up entering the economic visions between determinists/liberalists and interventionists, both engulfed by positivism and mathematical reason that has left out any transcendental dimension. With these assumptions, this article pretends to present the fundamentals of economic phenomenology, a branch of phenomenology that studies economics in the formation of its primary ideas in response to the economic positivism that left any transcendental dimension and questions out of the economics science, such as: what kind of society do we want? In this context, the principles of economic phenomenology take form from the relationship between subject (intention) and materiality, noesis and noema (Noesis is the intention, the subjective dimension. Noema, is the object thought in subjective terms), which always presupposes a concept, an idea that can be interpreted in everyday life. In this direction, it also proposes the presuppositions, the method, some concepts and theories of which economic phenomenology is composed. Among these, the concepts of ontological reason, Peoples rights demand, the meso-economy and the theory of wages in order to interpret the vision of life that underlies economic systems.
\end{abstract}

Keywords: economics; positivism; phenomenology; theory; ontology

Reference to this article should be made as follows: Vigliarolo, F. 2020. Economic phenomenology: fundamentals, principles and definition. Insights into Regional Development, 2(1), 418-429. http://doi.org/10.9770/IRD.2020.2.1(2)

\footnotetext{
${ }^{1}$ This research was supported by the project, which has received funding from the European Union's Horizon 2020 research and innovation programme European Research Council (ERC) under the European Union's Horizon 2020 research and innovation programme Marie Sklodowska-Curie Research and Innovation Staff Exchanges ES H2020-MSCA-RISE-2014 CLUSDEVMED (2015-2019) Grant Agreement Number 645730730
}
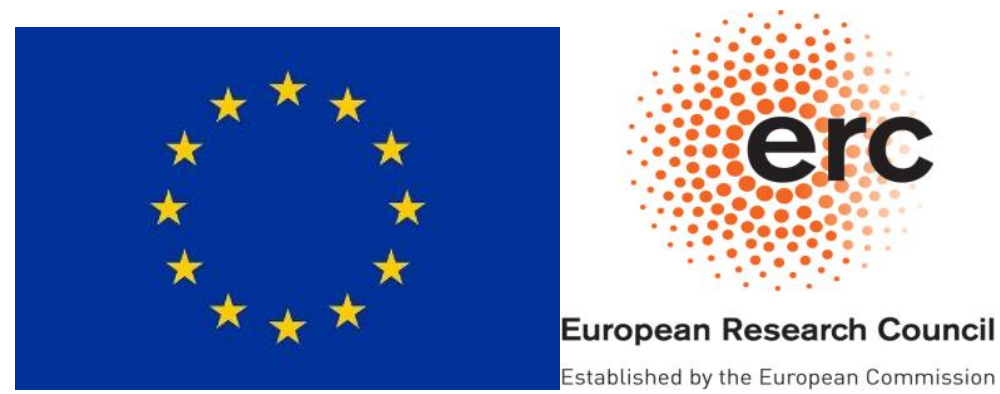
INSIGHTS INTO REGIONAL DEVELOPMENT

ISSN 2669-0195 (online) http://jssidoi.org/jesi/

2020 Volume 2 Number 1 (March)

http://doi.org/10.9770/IRD.2020.2.1(2)

JEL Classifications: A10, N01, P00,

Additional disciplines: sociology; phenomenology.

\section{Introduction}

With Marx, to which some critics, rightly or wrongly, attribute having "turned up side down" Hegel, one of the greatest idealists of Kantian imprint, the tension between structure and superstructure ended up entering the economic visions between determinists/liberalists and interventionists (for example, the dichotomy between classics and Keynesians which are the two main schools of economic thought in the world). We can say that the basic point on which they debated is what the Being of societies is, what is essence, structure, and what is not. In other words, even the assumptions of the evolution of the man in history, whether they are ideals (and defined by man in his conscience) or materialistic (that is, dependent on the material conditions to which man tends or contends). The ideals issues have been left out by economic positivism and today, in the era of economic financialization (defines as the growing relationship of financial values on the gross domestic product of a country or the world), are crushed by an economic vision that coincides with the accumulation of financial values (the $95 \%$ of financial values have not relation with goods and service) without relation with natural and human substance of society, as Polanyi called it (Polanyi, 2000 [1944]).

We can define economic positivism as the scientific current that studies economic systems "as they are", based on mathematical rationality and on the maximization of individual interest; it leaves aside normative considerations such as "what kind of society do we want to build?". In his book Studies and Exercises in Formal Logic (1884), the father of the famous Keynes, became famous for his expressive clarity and for rejection mathematical symbolism. In his most important classical work of economic methodology, The Field and Method of Political Economy (1891), he classifies existing approaches to economics as inductive or deductive. With this book, Keynes has opened new lands by integrating both approaches, defining the positive economy as the study of the economy "as it is" and the normative as "it must be". Arguments also addressed by Milton Friedman, who later states that: "Positive economics is, in principle, independent of any ethical position or regulatory judgments. Taking up Keynes himself, he refers to "what it is" and not what "it should be". Its task is to provide a system of generalizations that can be used to make correct predictions about the consequences of any change in circumstances. Its operation must be evaluated based on the accuracy, scope and compliance of the forecasts provided with the experience. In short, positive economics is, or can be, an "objective" science, in exactly the same sense as any of the physical sciences" (Friedman, 1953: 9).

It is in this scenario, that the economic phenomenology is placed, whose principles are set out in this article (Vigliarolo, 2019). This is the result of the attempt to insert the value of intentions into economic relations and to interpret them with materiality as ideas, concepts that determine a vision of life, redefining the relationship between structure and superstructure in terms of priorities and not dichotomous one. In other words, the structure is formed by the relationship between idealism and materialism, through what the "ego" defines in consciousness in the permanent interaction with "the everyday world" from which it feeds back (Schütz, 1962). All this is the objective of the economic phenomenology whose principles, in more details, have been exposed in the mentioned book after having dealt with a historical and theoretical analysis of the concept of economy from its birth to the present day. In this article, after having proposed the assumption and the definition, we can read some parts, such as the method, the principles and the theory of the of wages linked to the production of goods and services (Vigliarolo, 2017), with which the phenomenological approach interprets the economy in terms of the construction of potential identities (rights) of a society or community. In the cited text, they are examined in depth as these also depend on social and territorial vocations, by the ways in which we live, and also on the feelings and behaviors that underlie economic relations. 


\section{INSIGHTS INTO REGIONAL DEVELOPMENT}

ISSN 2669-0195 (online) http://jssidoi.org/jesi/

2020 Volume 2 Number 1 (March)

http://doi.org/10.9770/IRD.2020.2.1(2)

To this end, it contrasts utilitarian reason with ontological one and proposes that this last is constituted and interpreted in the meso-economy; this is a place of formation of the social conscience created for groups who define together potentially universal priorities that are not only belonging to a class consciousness, such as for example transversal values like the environment or the priority ideas that recall the necessaries goods and services for the historical functional to the ontological construction of human life. Historical assets are those that identify a People and are functional to identity in the long term as opposed to those functional to the market, in the short term. In other words, we could also call them "goods subjectively considered part of the being of the world in objective terms", when they are recognized by the conscience as subjectively necessary to personal and community life, and therefore influence the historical trajectory of a community, a territory. Therefore, they are structural assets with high added value and, for these reasons, they are placed in an extreme diametrically opposed to the goods used to carry out the accumulation of capital or only commercial (used in the short term and short life). For example, a motorcycle that has a life of 20-30 years compared to the same motorcycle that has a life of only 3-5 years made only for a commercial value (Vigliarolo, 2019: pages 172 and foll.).

For this reason, it can be affirmed that economic phenomenology observes the construction of the ontological reason of Peoples and always refers to a demand for rights and not for consumption, this one is interpretable by progressive degrees of social consciousness, through the relationship between noesis and noema always present potentially in economic relations.

\section{The assumptions of the economic phenomenology}

The rights of men and women who live in a society, as phenomenological aspects of individual and social being, while on the one hand are something that are born (as a potential structure) with human beings, also depend on the conditions that are installed in the society and, first of all, in the economic system in order they can have their full realization. Without roads or means of transport, our right of movement would be limited. Without a home, our right to live protected from the weather and live in a house with our family would not exist. Without the production of artifacts, many phenomenological aspects of our way of being like sitting, sleeping in a bed, drinking in a glass, etc., would be limited and would affect our social rights. But still, without being able to go to school and receive an education from teachers, our right to education would also be limited. Without food, our primary right to life would not exist. And so, for many other aspects that can be added and that are part of what can be called "the ontological reason" of social life that emerges from the relationship with materiality, between noesis and noema, which is always a concept, an idea, a function that needs to be interpreted. All this implies that, if on the one hand we are born with an ontological dimension that we carry inside, it is pure power until it is implemented through the organization of daily life that involves the management of resources. Therefore, resource management implies the possibility of developing aspects of life that the "social conscience", manifest or latent, allows to understand as important or essential for our life (individual and communitarian). These dimensions can be called ontol ogical priorities of social life in the economy that occur as a result of the effort of men who relate to each other, and which presupposes the use of the labor force that transforms reality and produces the conditions for living together. Therefore, the material dimension of life potentially contains a meaning attributed by men themselves according to their needs, on the one hand, and their subjective dimension (principles and values of reference), on the other, which are defined and objectified in reality (experience) and cannot be reduced only at a monetary benefit cost.

All this implies a dimension of consciousness which we will call "a priori". But this dimension of consciousness determines "concepts of human thought" objectified with the use of goods and services. These concepts can be simple or complex. For example, food satisfies the need to eat and, when it is objectified by experience, it is inscribed in the consciousness as an idea of eating that people deem necessary to carry out other human and social projects; similarly, when using a car, this contains both the idea of transport and the being that is transported; a 


\section{INSIGHTS INTO REGIONAL DEVELOPMENT}

ISSN 2669-0195 (online) http://jssidoi.org/jesi/

2020 Volume 2 Number 1 (March)

http://doi.org/10.9770/IRD.2020.2.1(2)

chair contains both the idea of sitting, resting, etc., and so on for other goods and services or intangible or relational goods (Donati Solci, 2011) such as training, study that represent the idea of learning, developing skills, laying the foundations for a future work, etc. All of this can be defined as the presupposition of economic phenomenology.

\section{Definition}

By the assumption just described, economic phenomenology can be defined as the branch of phenomenology that aims to study economics in the formation of its primary ideas, which contribute to the creation of a country's structure and vision of life, a society, starting from the pure consciousness that opens up to the world, through the relationship between noesis and noema. In this direction, economic phenomenology studies the coherence of economic systems with respect to these ideas considered as priorities in human consciousness that can be converted into social, and how these can represent the structures of an ontological reason that allows the implementation of what we call the being of the world.

For these reasons, it is proposed that the economy can be understood through a "demand of rights" and it presupposes an "ontological reason" that is determined and interpreted through "the subjective intention towards an object" (a good or service). This cannot be reduced only to a monetary value but to the social and human function that the goods and services determine, and it is interpretable with the language that expresses the concepts, the ideas. We also refer to Heidegger's conception according to which "the ontology is determined through the knowledge that man assumes after reflection on the structures of 'being', considered elements that give meaning to the world" (Heidegger, 2011 [1927]: 15) and he states the language is being's house (Heidegger, (2011 [1927]).

This "ontological reason" or "demand of rights" is determined subjectively in a stage defined as "mesoeconomia", an intermediate stage between the micro and the macro economics, conformed to social groups that channel individuality (civil society, productive sectors, etc.), as will be explained later.

In this context, economic phenomenology proposes to observe social consciousness as a "set of social meanings" in the different degrees with which an economic action appears. These elements can only be recognized by "intersubjective knowledge" and for these reason they determine what we will call "the relational and constitutive rights of being". Therefore, the "social conscience" determines, potentially, what we call "ontological relationship", which is the human and social sense that is incorporated in the economy left out, as we said above, from economic positivism. In other words, ontological relationships provide the concrete dimensions of the elements that contain the priorities that animate the visions of life. Each relationship can have different priorities and not necessarily each one is interpreted in the same way. For these reasons, they may have general and particular characteristics. These ones are related to the noematic dimension and imply what we can define an economic aesthetic that is they change according to vocations, tastes, innovations, etc. A road carries within it a basic idea, that of walking. Asphalt is a secondary idea (a particular characteristic), as its coverage could be made with asphalt, concrete, stones or other material, depending on the needs or tastes; these are characteristics that define what we call economic aesthetics (Vigliarolo, 2019).

So, general ones are pure form; particulars are the modalities or the content of the general ones. For example, the idea of eating implies the ways in which it takes place, the different types of food; the right to move can take place in various ways (car, train, on foot, etc.); and so on. The coincidence between pure form and content or their mode of realization determines what we call an economic noumenon. It can be defined as the coincidence between the intentional subjective dimension and the content of economic action that expresses in itself an observable noematic dimension and referable to a potential dimension of being. He defines it as noumenon because it contains the ideal intelligible dimension but is determined by the sensitive dimension, thus it unites 


\section{INSIGHTS INTO REGIONAL DEVELOPMENT}

ISSN 2669-0195 (online) http://jssidoi.org/jesi/

2020 Volume 2 Number 1 (March)

http://doi.org/10.9770/IRD.2020.2.1(2)

materialism and idealism into ideas, real concepts that the economic system brings forward. For example, the idea of eating is real because without eating we can not live and we can experiment it in the reality, etc. for different ways of being, rights, which can be achieved in several ways, but these modes do not always implement what we really want. The system itself may not carry forward the intention and real ideas. When this happens then we are faced with an economic noumenon, that is the coincidence between a real idea a priori and the ways to achieve it in the experience, while the economic phenomenon is what appear and it needs of interpretation to undestand if it is noumeno, a real socio-economics truth condition. So, the economic noumeno it is always referred to an interpretable ontological condition; it's what we want in the intention that is transformed into the ideas that we believe are exactly reflected in management, goods and services. We can also say that the dimension of consciousness is directly implemented and in this way idealism and materialism contribute to the definition of the same concept by feeding back. We cannot really assume the idea of eating without food, the idea of moving without roads, the idea of knowing without education or training, etc. (elements that can be considered necessary to allow everyone to be able to carry on their life project if they do not contradict each other). For these reasons, as mentioned in the introduction, the tension between materialism and idealism according to this approach is resolved in priority and not dichotomous terms. Furthermore, there are values, priorities, ideas that are transversal to all social classes and depend on the management of the system, such as the environment, or human rights (Vigliarolo, 2019). So, this is a "moments of socio-economic truth", which contain an idea that is carried forward by the management of resources and the production of goods and services.

Thus, according to economic phenomenology, the assumptions of economic truth do not lie in mathematical rationality, but rather in human decisions ("ontological intentions that transform in ideas, concepts, values, ...") and depend on the consciousness that is socialized and determines what is necessary for the life of the community. We can call this process as "eocnomic socialization" and can be defined as the process that involves relating on the basis of values and priorities dictated by human visions that are incorporated into the economy in terms of production process and consumption.

In this direction, therefore, economic phenomenology is concerned with observing the economy in its ontological, and non-utilitarian, rationality, as a vision of life behind economic facts, through the priorities that are considered as such in the "conscience" and in their ways of implementation. For these reasons, an ontological reason must be observed in the impact that economic events have on the level of the rights of a community (condition of being) and, therefore, in the vision of life that animates the social life of all the observed relationships, up to human consciousness. This is called transcendental economic reduction, which can be a priori or a posteriori. As we will see in the next section where we expose the method.

\section{The method}

The observation is based on the subjective relationship that emerges from an intention that potentially contains an ontological dimension that eventually requires the formation of primary ideas that are inscribed in the individual consciousness and, when a social expectation is created, are considered "human priorities (this is what we call the "economic socialization process"). Therefore, it is a question of observing how, from individual intentions, conscience (even social intent) is built and animates an economic system, an ontological relationship, etc. So, we can ask ourselves: how to observe the dimension of the social conscience that animates an economic system resulting from individual actions? How to interpret the primary ideas of an economic system through the relationship with materiality?

Starting from these questions, we have the process that we call economics phenomenological reduction. It reduces the economy in ideas that derive from intentions and that subsequently model the relationships of a system. Therefore, we can affirm that the phenomenological reduction in economics occurs through the interpretation of 


\section{INSIGHTS INTO REGIONAL DEVELOPMENT}

ISSN 2669-0195 (online) http://jssidoi.org/jesi/

2020 Volume 2 Number 1 (March)

http://doi.org/10.9770/IRD.2020.2.1(2)

subjective meanings (which are the basis of the relationship between noesis and noema: in Heidegger terms, we can say the meaning of the projects of the man who living together) bringing them to their extreme consequences (also in terms of processes). So we can observe the rational subject and its potentially "universal" dimension inserted in the context in which he lives. That is, behind a relationship with materiality there is a set of characteristics that shape the rational subject that animates the social essence and determines the structure of the systems. As we have said, a house implies the idea of living under a roof; a car can represent the idea of moving, etc. They are ideas that define the essence of the subject which, in turn, defines the system. If all individuals want to have a home and move, the subjects are supposed to consider it as necessary and it determines a social conscience. In the measure in which it is constituted by the relations between subjects and the same materiality, it encourages economic relations to maintain these rights (we have an expectation). Economics phenomenological reduction, also assesses if the ideas can conflict, be against or not be completely consistent with the priorities of the initial rights mentioned. In other words, it is observed if the real intentions of systems and relationships can coexist ("having a roof" and "moving") and how they depend on the processes and organization of the social life. The economy is reduced and interpreted, thus, to primary intentions that determine the primary ideas that animate the system. And this also serves to interpret the ethical principles or other factors that influence the social relations behind every economic process.

The reduction can be made a priori, simply by interpreting the idea that follows from the intention directly observed with the object. This is led to its extreme consequence in ideal terms; or a posteriori, analyzing in a time frame what the intention actually produces at the general level. The two dimensions (a priori and a posteriori) can be fed and, since it is impossible to reach the end of time, in the absence of stable or present data, ideas are brought to their extreme consequences subjectively. Therefore, a subjective interpretation of the intention (economic reduction) is determined with progressive degrees of objectivity and this is why it is stated that the economy is a social phenomenon and, as such, is not an exact science according to mathematical laws.

For example, capitalism has a phenomenological relationship of direct intention with profit or capital circulation, which in its extreme consequences does not allow us to understand what kind of social order is conformed as rights since the profit itself, as a noema. Because it is not linked to human priorities and social; it lacks a social conscience linked to something considered important; that is, it has not observable noematic content. Finally, the phenomenological reduction determines the human and social priorities as ideas of community life and it is what we call the world's vision that the economy carries on through its production and management of material resources.

\section{The general principles of economic phenomenology}

After all these arguments, the general principles of economic phenomenology can be summarized in the following points:

- The intelligibility of an economic system is based on the existence of primary ideas that must be implemented in practice in order to objectivize (pure reason is transformed into practical reason) and permanently create those "answers or elements" to a need or a real vision.

- These ideas, when they are constructed in an intersubjective manner, define the "we" and generate the context where the individuality can act freely to develop the conditions that implement the priorities of life. For these reasons, relationships are animated by what is called "expectations" which can be positive or negative. That is, positive when the other hopes that everyone behaves with the same ratio that the system can carry out; negative when the other behaves in a contrary or different way to a vision of common life or pursuing only individual interests (which is the area of crematistica; from Greek, is the area defined by Aristoteles that pursuits personal interests of material richness). 


\section{INSIGHTS INTO REGIONAL DEVELOPMENT}

ISSN 2669-0195 (online) http://jssidoi.org/jesi/

2020 Volume 2 Number 1 (March)

http://doi.org/10.9770/IRD.2020.2.1(2)

- In this context, an economic system must always be considered holistically; this means that it must consider social, political, institutional, financial, productive and commercial parts. In order to work, these must be coordinate and oriented by a "social pact" (demand of rights) that outline the ontological reason.

- Politics and the State must guarantee the conditions of common life such as infrastructures, norms and avoid opportunist behavior that damages community life. This is necessary to allow the system to develop collectively and to guide and promote free individual initiative towards strategic sectors of social life as a single body.

- Only investments expand the system and can be of two types: capital and human knowledge and work (bearing in mind that time is always present in all the factors that are used). Capital investments derive from savings, but not all the savings invested go towards increasing the production related to the vision and the needs of life that can be directly understood. Part of saving can be invested to make money and this produces a loss of intelligibility of the system and in phenomenological terms does not necessarily generate a satisfaction of real needs (or identity).

- Savings can be private or public (of the State). Private savings are determined in families and enterprises and it is the one that most likely determines the growth of responses related to human needs. It has a direct intention with goods and services. We call this one genuine save and derives from the wages and productivity level of a country.

- Investments need the labor force: but without the "knowledge" embedded in the "human resources" a production of functional or historical quality goods is not generated.

- Only a minimal part of save must be used for accumulation purposes for purposes defined as necessary and strategic, or for unknown events or events that may occur.

- The necessary savings is the amount of resources needed to answer a foreseen or unexpected need in the future. It's strategic when it refers to the fact that there are strategic sectors that in the future can be the object of family investments such as education, health, tourism, etc.

- Investments can be interpreted in terms of vision of life if they are linked to aspects of real life. There is a minimum level of investment necessary to activate structural changes and this depends on the ability of countries to react to their situation of need or to crises. The ability to react depends on becoming aware of what is important for the people and their need to reach it. Therefore, a country, a region or any other territorial organization must have an investment plan linked to the priorities of social life. What we have seen is called "social function", disappeared with the emergence of mercantilism (Vigliarolo, 2019).

- The meaning of a good is determined only through the interaction of the subject with the object. This, in turn, defines a concept, an idea that is written in the consciousness and determines the priorities of individual and community life. By determining these conditions, its monetary value cannot be defined only by the law of supply and demand (scarcity-quantity), but must have a relational value that varies according to its capacity to satisfy the conditions of private and community life.

- Each People has its strategic sectors related to the priorities and the socio-cultural and geographical-territorial conformation. These allow to generate comparative advantages (both for added value and for natural resources) and to feed other sectors. 


\section{Micro, macro and meso-economics}

Economic micro-phenomenology observes and studies the ontological relationship with the materiality that is built locally through the direct relationship and the process of knowledge formation with the whole context.

Economic macro-phenomenology, on the other hand, observes the ontological reason thanks to typed knowledge. It also observes how this is determined and implemented by macro-systems (national and international) so that aggregate demand of people's rights is implemented.

Economic phenomenology presupposes a third space that is intelligible in terms of social consciousness: the meso-economy. It is that part of the economy that is determined through the existence of "groups" that have, on the one hand an interpretable social intention and, on the other, an autonomous dimension with respect to the macro economy, because there is an interpretable social vision and that the system could not do it only with the deficit or other positivist variables.

In this context, the meso-phenomenology economy implies strategic sectors to which they are attributed a social meaning based on the function they perform; the set of values (social, environmental, etc.) that a country or a society must promote to limit individual interests and promote collective construction. This does not depend on class consciousness, otherwise the loss of the ontological reason of social life is generated. In this context, it deals with orienting the economy through strategic production steps that can define the development of a country or a society in a global manner. For these reasons it studies:

- the forms of sectorial participation and the creation of coordinated value chains so that the actors have a common level of awareness.

- The medium and long-term strategic sectors necessary to develop the aggregate demand for the rights of a company in order to maintain a coherence between the system and the ontological reason of a People.

- The capacity for strategic savings.

- The capacity of the workforce oriented to the development of these sectors.

- The social system (education, training, infrastructures, standards, sectoral financial interest rate, among others) necessary to guarantee instrumental goods and services essential for the development of strategic sectors.

- The strategic sectoral demand for goods and services that support only part of the global demand of rights.

- The general conditions for developing the productive advantages considered essential for life by the countries according to ontological priorities, including the skills of the workforce. All this can be observed with the strategic growth index (ICE):

ICE = value of goods and services related to strategic sectors

(including financial values and social and political institutions)

value of the total of goods and services

(including financial values and social and political institutions) 


\section{Theory of wages, equilibriums and aggregate demand of rights}

As a lens for realizing phenomenological observation in economics we can use the theory called "centric wage or rights".

Through this theory we interpret how the productive wages of goods and services are determined, considered them the heart of an economic system; this is done through the observation of the system as a whole, including human and territorial vocations, raw materials, training, institutions, etc., and how subjects orient their intentions in permanent investments towards goods and services that carry within them a vision of common life (which, as we have seen, are ideas, concepts).

According to this theory, it is envisaged that wages, obviously by degrees of specialization and labor force, must cover the set of rights deriving from goods and services defined at a meso-economic level, which means covering a "demand of rights" established in the "social pact" for a determined level of equilibrium and, at the same time, to always have a percentage of "strategic" savings that is transformed into investments and that each family subjectively decides to do to affirm or extend its ontological dimension. So it can be summarized as:

Wages $+\%$ savings $/$ investments $=$ production of goods and services functional to the rights defined at mesoeconomic level

In formula: $W+\% I=P$ meso-economic $(W=$ wages; $I=$ Investments; $P=$ production $)$.

Circular equilibrium situation (see Figure 1):

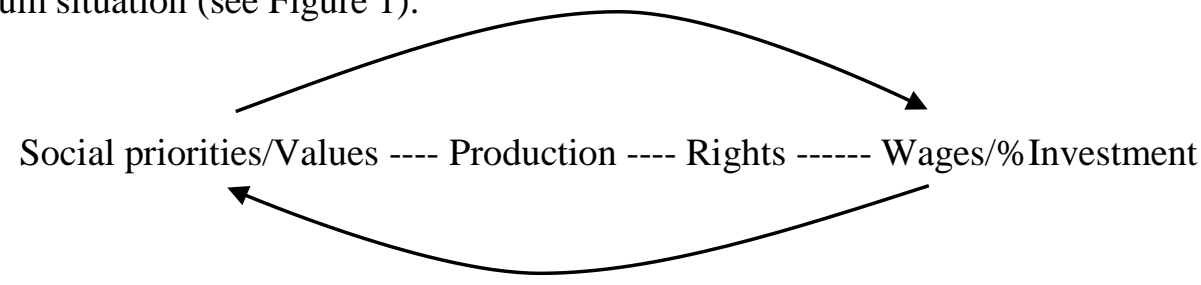

Figure 1. Circular equilibrium situation

The equilibrium is dynamic in that once established a base of rights we can incorporate others that are born or become established in society permanently, up to its defined stage of "development" (also in permanent evolution). Therefore, for each equilibrium an aggregate demand of rights is defined, defined as the set of rights related to each other necessary to develop the ontological reason of Peoples at a given moment. For example, the right to education can have an impact on the right to work, etc.

According to this theory, the percentage of savings foreseen in wages has a direct relationship with the growth rate of the country.

The latter in turn must be related to the tax of active interest of the financial system (cost of money) and prices as a phenotypic aspect of the values of the goods and services we have seen, must remain such as to allow the progressive implementation of growth stages and expansion of rights. This means that the percentage change with 
the acquired power must remain stable otherwise the investments and the acquired rights are reduced (the salaries must be linked to the established rights).

If these aspects do not have a coherence between them, situations of imbalance are created where phenomena such as the growth of financial values without relation to the real economy, the fall in purchasing power that damages established rights, etc. can occur.

The system stabilizes when the quality of production grows in quantity (without exceeding real needs) and quality pluralistic production stabilizing the downward prices and allowing to increase the percentage of investment that is oriented towards new rights, or stabilizing the acquired ones, permanently. Graph of aggregate demand of rights for different levels of equilibrium is presented below (Figure 2).

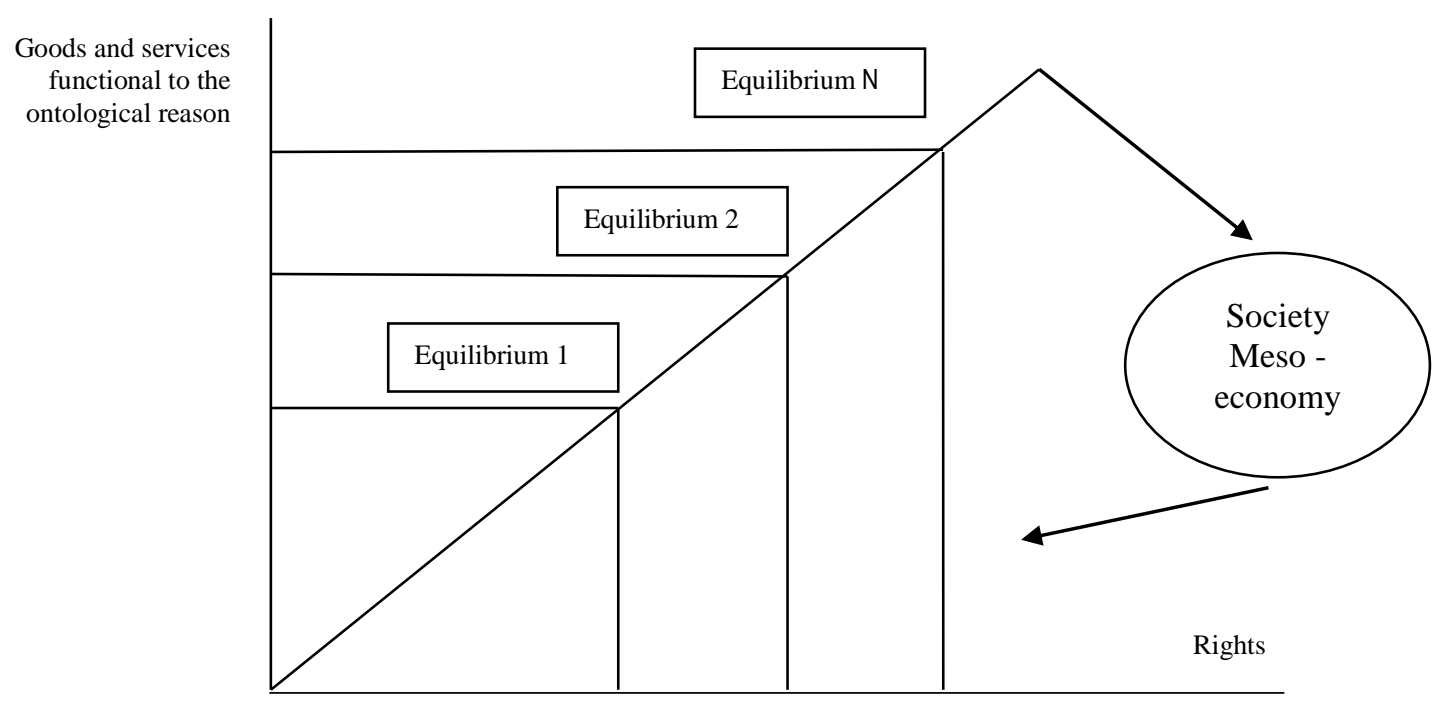

Figure 2. Graph of aggregate demand of rights for different levels of equilibrium

\section{Conclusions}

Economic relations are social relations and cannot be reduced only to monetary or material benefits, but they hide a potential ontological dimension that is interpreted and directed by the relationship with the materiality that defines a human identity in continuous construction. In this way, the demand and supply of goods must be read as a part, above all, of the construction of the social identity of a People. It involves the definition of ideas and a vision of the world that implicates ontological conditions of people in their community that are built in a relational way (and, therefore, cannot be measured only in individual terms). For these reasons, we speak of the demand of rights of Nations, and we propose to observe these relationships through a phenomenological approach because it permits to interpret it. Among the areas of application of this approach we can mention some such as the processes of development of Peoples in its various scales, from a territorial dimension to the regional, national or international one. In other word, we can affirm that we cannot understand an economic system without understand what is important for a society, Peoples or the whole Humanity in terms of social meaning and function. Otherwise it misses of an intelligible dimension. 


\section{References}

Finley Moises I., 2008. L'economia degli antichi e dei moderni, Laterza, Bari.

Friedman Milton, 1953. Essays in Positive Economics, Chicago University, Chicago.

Donati Pierpaolo, Solci Riccardo, 2011. I beni relazionali. Che cosa sono e quali effetti producono, con Riccardo Solci, Bollati Boringhieri, Torino.

Heidegger Martin. 2011 [1927]: El ser y el tiempo, Fondo de Cultura Económica, México.

Husserl Edmund, 2008 La crisis de las ciencias europeas y la fenomenología trascendental, Prometeo, Buenos Aires.

Husserl, Edmund, 1986. Ideas relativas a una fenomenología pura y a una filosofía fenomenológica, Fondo de Cultura Económica, México.

Kant Immanuel, 1788. Critica della ragion pratica, Editrice Bompiani, Milano, 2004.

Kant Immanuel, 1781. Critica della ragion pura, III Edizione, Editrice Tascabili Bompiani, Milano, 1991.

Keynes John Maynard, 2012. Teoría general de la ocupación, el interés y el dinero, Fondo de Cultura Económica, Buenos Aires.

Keynes Naville, 1884. Studies and Exercises in Formal Logic, Macmillan and Company.

Keynes Naville, 1999 [1891]. The Scope and Method of Political Economy, Batoche Book.

Polanyi Karl, 2000 [1944]. La grande trasformazione, Einaudi, Torino.

Schütz Alfred, 1962. El problema de la realidad Social, Escritos I. Amorrortu, Editores Buenos Aires-Madrid, 2003.

Schumpeter Joseph, 1990. Storia dell'analisi economica, Bollati Boringhieri, Turín.

Smith Adam, 2013. La Ricchezza delle Nazioni, UTET, Novara.

Vigliarolo Francesco, 2017. Lupi e agnelli. Societá capitaliste e vie d’uscita, Jaca Book, Milano.

Vigliarolo Francesco, 2019. La economía es un fenómeno social. Principios de fenomenología económica, Eudeba, Buenos Aires. 
INSIGHTS INTO REGIONAL DEVELOPMENT

ISSN 2669-0195 (online) http://jssidoi.org/jesi/

2020 Volume 2 Number 1 (March)

http://doi.org/10.9770/IRD.2020.2.1(2)

\section{Aknowledgements}

This research was supported by the project, which has received funding from the European Union's Horizon 2020 research and innovation programme European Research Council (ERC) under the European Union's Horizon 2020 research and innovation programme Marie Sklodowska-Curie Research and Innovation Staff Exchanges ES H2020-MSCA-RISE-2014 CLUSDEVMED (2015-2019) Grant Agreement Number 645730730
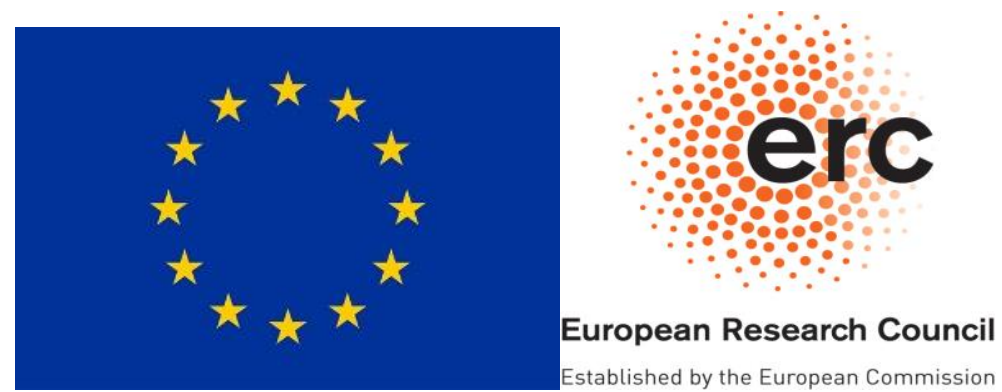

Francesco VIGLIAROLO is full profesor of regional economics in Catholics University of La Plata, Argentina. His principales books in the subjetc are "Lupi e agnelli. Societá Capitaliste e vie d'uscita", published in Italia with Jaka Book Editor and "La economia es un fenomeno social. Principios de fenomenologia economica" publishd in Argentina with Eudeba.

ORCID ID: orcid.org/0000-0002-9667-3730

Register for an ORCID ID:

https://orcid.org/register

Copyright (C) 2020 by author(s) and VsI Entrepreneurship and Sustainability Center

This work is licensed under the Creative Commons Attribution International License (CC BY).

http://creativecommons.org/licenses/by/4.0/

(c) (i) Open Access 